\title{
両船の見合関係に関する一考察
}

\section{A Study on the Appreciation of Risk of Collision between two Vessels}

千 原 義 男 (航海訓練所)

\section{1. まえがき}

両船の見合関係において、航海士は他船との相対関係を認知、判断し、更に将来の態勢を予測 し衝乫の危険性の発見及びその評価を行うとともに、航行規則、自他船の運動性能、周囲の状 況、風潮の影響等多くの条件を勘案して自船の行動を決定する。更に避航処置の必要な場合に は、正しい手続に従つて時機を誤またずに回避行動を発動し、その後の相対関係の変化に留意し ながら、安全に航過するように運航しなければならない。

この過程において、先ず第 1 の段階である他船との相対関係の把握と、それにもとずく衝䞐の 危険性の発見及びその評価が確実に行われる必要があり、この段階における失敗は、その後の過 程に致命的な失敗をもたらす重大な原因となる。

衝突の危険性の発見及び評洒を行う上において、視覚見張によつて得られる情報が最も重要な

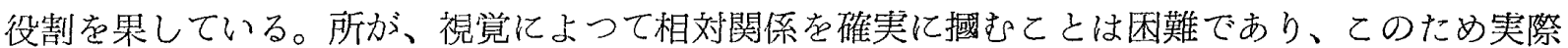
の運航場面においても、過激な行動によつて回避しなければならないような緊急な態勢に立入ら

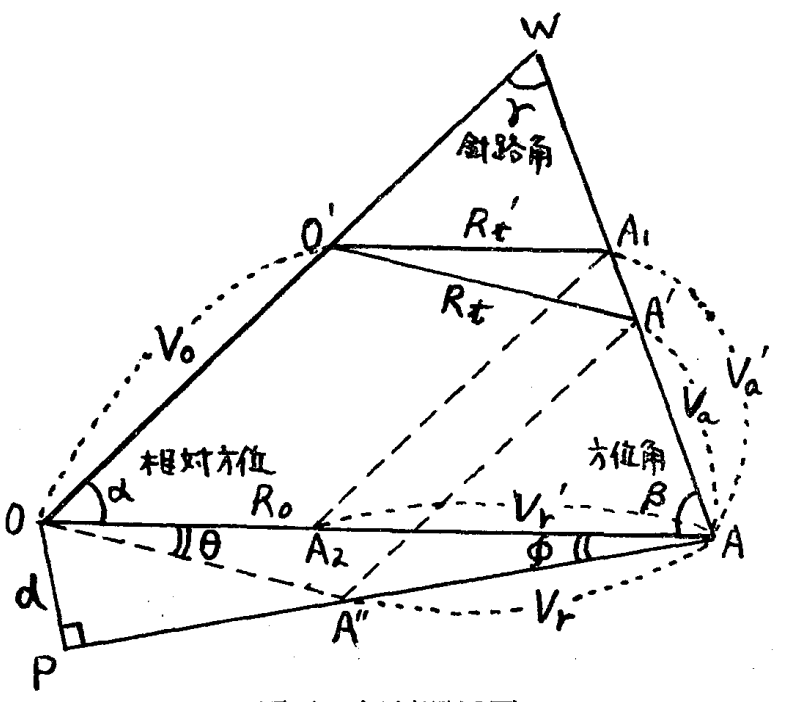

図 1 相対関係図 ないように、早期に汹るかかな回避行動が取ら れる場合が多い。このような点について、相対 運動の簡単な数学的解析を行い、この解析にも とずいて相対運動を視覚により認知し、衝突の 伦険性を発見及び評価する場合の問題点を検討 した。

\section{2. 他船の方位と衝突の危険性の発見}

図 1 は両船の相対関係を図に示したものであ る。雨船が衝突条件にある場合には、 $\triangle W O A$ のスピードベクトル図が成立する。ての関係を 式によつて表わすと次のとおりである。

(衝笑条件の場合)

$\triangle A A^{\prime} A^{\prime \prime}$ ：同上(衝乫条件でない場合 $O W$ : 自船針路 $\quad V_{0}$ : 自船速力 (浬 $/ \mathrm{min}$.) $A W$ : 他船針路 $\quad V_{a}, V^{\prime} a$ : 他船速力 (浬 $/ \mathrm{min}$.) $A O, A P$ : 相対針路 $V r, V^{\prime}{ }_{r}$ : 相対速力 (浬 $\left./ \mathrm{min}.\right)$ $R_{0}$ : 最初の相対距離(浬) $d$ : 最接近距離(浬) $R_{t}, R^{\prime}{ }_{t}$ : 時間 $t$ に扮ける相刘距離(浬)

$$
\sin \alpha=A \sin \theta=\frac{A \sin \gamma}{\sqrt{1+A^{2}}-\overline{2 A \cos \gamma}}
$$$$
V^{\prime}=V_{o} \sqrt{1+A^{2}-2 A \cos \gamma}
$$

$$
\text { 但し } A=\frac{V_{a}{ }^{\prime}}{V_{o}}
$$

$A \leqq 1$ の場合、即ち他船の速力が自船より遅 


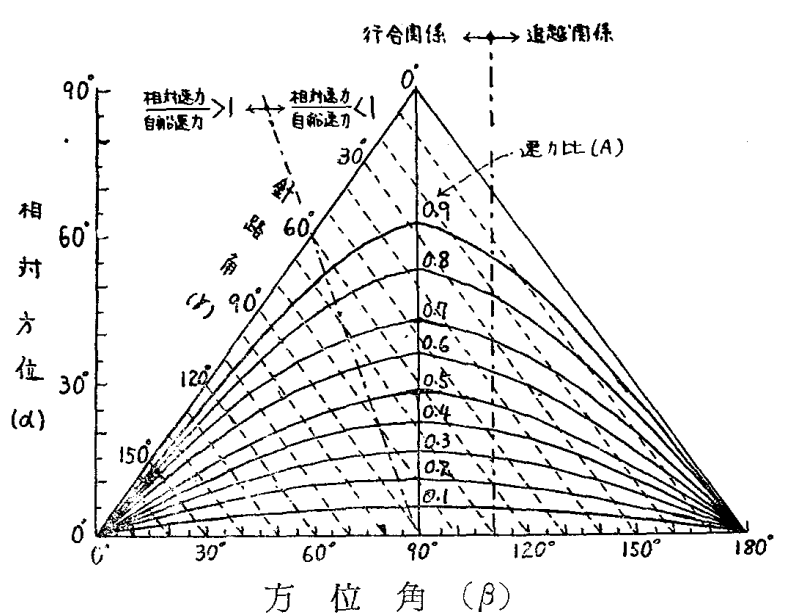

図 2 衝突条件に打ける雨船の速力比と関係 角との関係

表 1 日本沿岸における各速力の船船に遭遇する確率 （斎藤浄元民の資料より計算）

\begin{tabular}{|c|c|c|c|}
\hline $\begin{array}{c}\text { 明細琶速力 } \\
\text { (節) }\end{array}$ & $\begin{array}{c}\text { 实際速力 } \\
\text { (節) }\end{array}$ & 隻 & 碓 \\
\hline 4 & 3. 4 & 1 & 0.0006 \\
\hline 5 & 4.3 & 3 & 0.002 \\
\hline 6 & 5.1 & 18 & 0.012 \\
\hline 7 & 6.0 & 92 & 0.059 \\
\hline 8 & 6.8 & 212 & 0.135 \\
\hline 9 & 7.7 & 274 & 0.175 \\
\hline 10 & 8.5 & 302 & 0.193 \\
\hline 11 & 9.4 & 195 & 0.124 \\
\hline 12 & 10.2 & 90 & 0.057 \\
\hline 13 & 11.1 & 100 & 0.064 \\
\hline 14 & 12.0 & 118 & 0.075 \\
\hline 15 & 12.8 & 55 & 0.035 \\
\hline 16 & 13.7 & 48 & 0.031 \\
\hline 17 & 14.5 & 42 & 0.027 \\
\hline 18 & 15.4 & 7 & 0.005 \\
\hline 19 & 16.3 & 6 & 0.004 \\
\hline 平均 10.94 & 平均 9.85 & 訫 1,563 & \\
\hline
\end{tabular}

（詿） 1. 日本船舶明細書昭和 32 年度，総屯数 100 世以上

2. 奏際速力は斎藤氏が裁決録と比較計算し た俻であり，明細畫速力の1/1.17である。
い場合について、(1)式の $\alpha 、 \gamma 、 A$ に代表的 な数值を入れて作図すると図 2 のようにな る。

この図より、例えば速力比 0.8 の遅い船と 遭遇した場合、相対方位が右䑪又は左舷 $52^{\circ}$ 以 よ上 $\left(180^{\circ}\right.$ まで)であると、針路角の如何にり らず衝突条件は成立しないというととであ、 このように遭遇する船舶の速力が自船より遅 い場合には、その速力比によつて或る相対方 位以上に扔いては衝突条件が成立しない範团 がある。又他船の速才が自船より速い場合に は、如何なる相対方位であつても、衝突条件 を生ずる可能性があるということがわかる。

今、現在の全船船の速力構成が明らかに なると、或る速力の船が種々異つた速力比 の船舶と遭遇する確率を求めるととがでさ る。日本の船舶の場合について、斎藤浄元 氏が調べられた速力構成より、或る速力の 船舶が種々の速力の船と遭遇する確率を計 算すると表 1 のおりである。この確率と 図2の条件とから、各速力の船舶につい て、各相対方位における衝突条件を生ずる 可能性のある船舶と遭遇する確率を求める ことができる。この確率は、或る相対方位 にいる船船についての衝突条件を生ずる礁 率と同様な傾向を示すものであると考える ことができる。

計算結果を図に示すと図 3 のとおりであ る。例党ば、正船首に船がいる場合、他船 の速力の如何によらず、衝突条件が生ずる 可能性は必ずあり、この場合の確率は 1 と なる。

図のように明細書速力 $6 \sim 7$ 節（実際速 力 $5 \sim 6$ 節）以下の低速船は、全ての相対 方位から接近する船舶と衝突条件を生ずる 可能性があり、それより速力が高くなる と、方位約 $30^{\circ}$ より大きくなるに従つて衝 哭条件の生ずる確率は漸娍し、速すが高い 程その傾向が著しくなるというととがわか る。もつとも、ここに示した傾向は日本近 海における一般的な条件の場合であつて、 
速力構成の変化、地域によるその差異、航路 事情等によつて傾向は異つてくる。

航海士は、衝乫の危険性の有無を判断する 場合、他船の方位、姿勢（方位角）、速力等 の状衅を認知するととによつて、大略の判断 を行い、更に他船の方位を連続的に観測し、 その変化によつてより確実な判断を行わなけ ればならないが、図 3 のような運航の場の条 件を考慮すると、自船の速力の如何によう て、遭遇する船舶の相対方位、及び他船の速 力について直接的に得られる情報の確度が、 衝突の伦険性の有無の判断の難易にかなり樑 い関係があることがわかる。

即ち、速力18～19節（実際速力15～16節） で航行中の高速船は、他船の方位が $30^{\circ}$ より 大きくなるに従つて、衝突条件を生ずる場合 が急激に少くなるので、湩続的に他船の方位

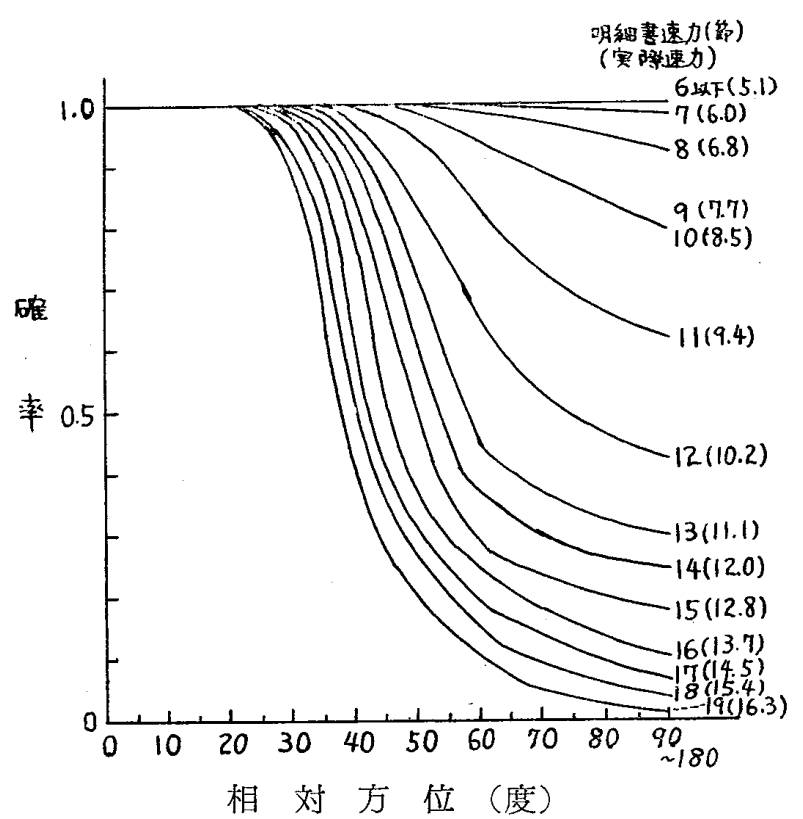

図 3 相対方位と衝乫条件が存在する確率との関係

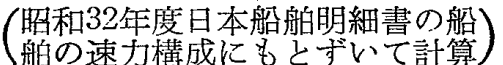
に留意しなければならない頻度が少くなり、更に他船の速力について得られる情報の確度が高く なると、衝乫の危険性の有無を容易に判断できる頻度が多くなるということが考えられる。速力 の遅い船になる程、このような傾向が少くなり、速力 $6 〜 7$ 節（ 5 〜 節）以下の低速船では、 このような傾向は殆んどなくなつて、全ての相対方位における衝突条件を生ずる頻度が殆んど同 じになり、専続的に他船の方位に留意しなければならない頻度は各方位とも殆んど差がないとい うことになる。しかし、以上のようなととは、高速船は後方見張をおろそかにしても良いという ことではなく、他船の相対方位が大きい場合でも、衝突条件を生ずる場合が、ある確率で存在 し、衝突の危険性の有無の判断は全ての方位にわたつて注意深く行わなければならない。なお、 夜間航海においては、他船の速力について得られる情報の確度は低下するので、何険性の有無の 判断が容易になるという条件は恶くなる。

\section{3. 他船の方位, 距離の変化と衝突の危険性の評価}

航海士は衝乫の危険性を発見するとともに、その仜険性を評価し、自船の行動を決定しなけれ ばならないが、衝突の何険性を評価するに当つては、他船の相対方位及び距離の変化が、その判 断の重要な基礎となる。

一般に回避行動は、予測される最接近距離の值が小さく、衝突の危険性の方が遥かに大きいと 判断されたとき始めて遂行されるものであると考えるて々ができる。

しかし、実際には、他船の相対方位、姿勢、相対速力等の状態を認知し、これらにもとずいて 子測される最接近距離は、両船間の距離にも関係するが、極めて愦差が大きく、特にその值が 小 さい時には、殆んど予測が困難な場合もあり、又衝突の仜険性の評価は、回避行動の発動が必要 な時機とも関連があつて、問題は非常に複雑である。

ここでは、回避行動発動の必要な時機は、如何なる相対速力の場合でも、時系列の上ではほぼ 一定時点にあると仮定して、相対速力及び最接近覑離の差異によつて、相刘方位及び距離の変化 の状況がどのようになるかについて数学的解析を行い、衝突の危険性の評価の間題を検討した。 
な抢、回避行動発動の必要な時㙨は、船の運動性能、外力の影響等によつても変化し、更にその 実際の決定に当つては、相対速力の時間の际数である相対距離の目測にもとずいて判断が行わ扎 るので、距離目測の確度によつても左有されるが、ての点については今後検傠を進める予定であ る。

(a) 他船の方位の変化

図 1 亿衝突条件でない場合の相対関係を示してあるが、自船の針路 $O O^{\prime}$ 、速力 $V_{0}$ 、他船の針路 $A A^{\prime}$ 、速力 $V_{a}$ とすると、相対針路は $A P$ 、相対速力は $V_{r}$ 、最接近趾離は $d$ となり、他船の り変化は $\angle A O A^{\prime \prime}$ 即ち $\theta$ で表わすことができる。相刘方位の変化 $\theta$ は次の式によつて求めるこ とができる。

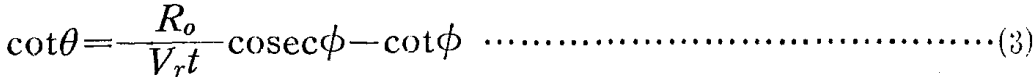

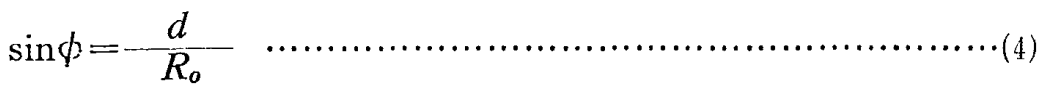

次に、実際には他船の方位の変化率が問題となるので、時間 $t$ の微小変化にとるなう万位の変 化を求める式を、(3)式を微分するととによつて得られる。

$$
\triangle \theta=\frac{R_{o} V_{r} \sin \phi}{V_{r}^{2} t^{2}+R_{o}{ }^{2}-2 R_{o} V_{r} t \cos \phi} \times \triangle t
$$

(5)式を最接近地点に至るまでに要する時間 $T$ （仮に最接近地点到撻予測時間と名付引る。）の 菡数に変換すると、即ち $t=\frac{R_{o}}{V_{r}} \cos \phi-T$ を(

$$
\frac{\triangle \theta}{\triangle T}=\frac{V_{r} d}{V_{r}^{2} T^{2}+d^{2}}=\frac{V_{r} d}{R_{T^{2}}{ }^{2}}(\mathrm{Rad} / \mathrm{min})
$$

\section{但し、 $R_{T}$ : 時間 $T$ における相対距離}

この式によつて、種々の条件の場合の任意の將間 $T$ における相対方位の変化率を求もるととが

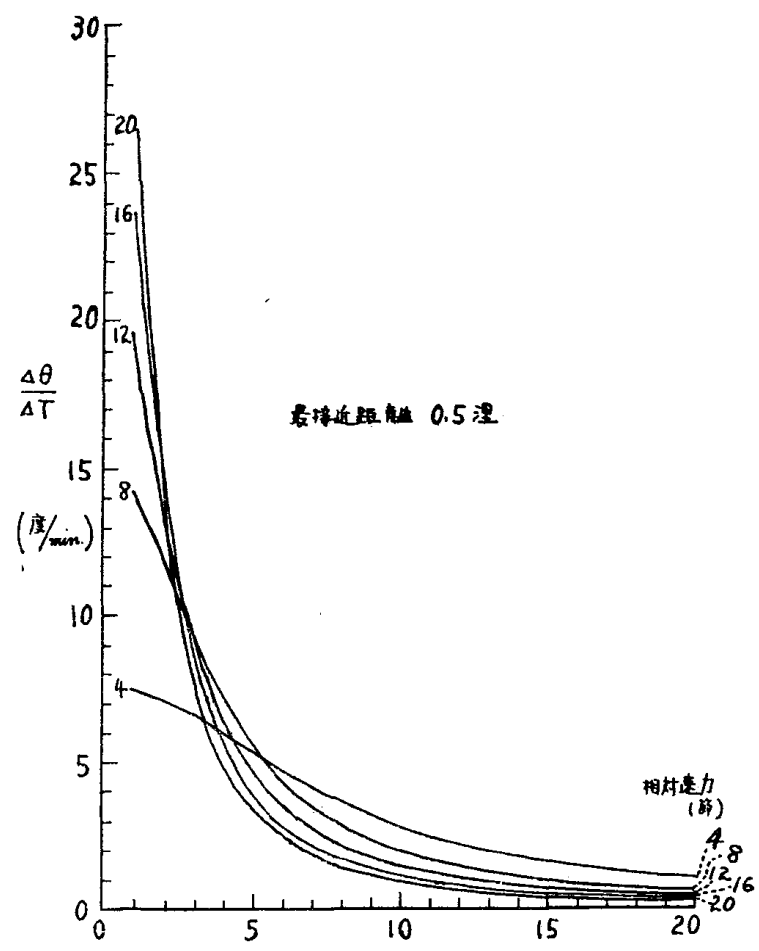

最接近点到着予測時間 $T(\mathrm{~min})$

図 4 最接近点に達する迄の相対方位の変化率 の経過

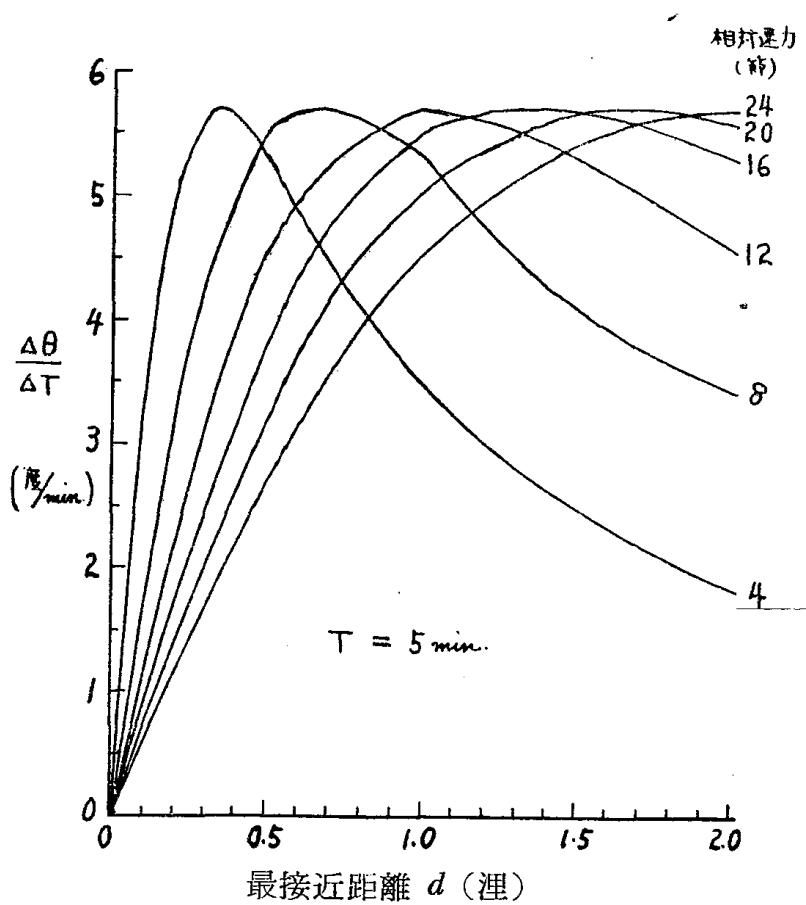

図 5 最接近点到着予測時間一定の時点に㗁ける 相対方位の変化率 
でさる。

最接近距離 $d$ が 0.5 浬の場合々、到陸予測時間 $T$ が 5 分の場合について、(6)式に代表的は数值 を大れて作図すると、図 4 及び図 5 の上うになる。この2 つの図より、次のようなととがわか る。

（1）到達予測時間が大きい時点に扔いては、方位の変化率は小さく相対速力の如何による差も 少いが、相対速力が大きい場合ほぞ、その值は小さくなつている。（図4）

（2）到達予測時閐が小さくなるに従つて、相対速力が大きい場合には、或る時点までのう位の 変化率の值の変化が少く、それ以後急激に増大するが、相対速力が小さくなるほど、変化率が徐 々に増大する傾问加強くなり、或る侍点 $\left(T_{M}\right)$ から相対速执大゙きい場合の変化率より小さく なるようになる。（図 4 ）

（3）乙の後者の時点（ $\left.T_{M}\right)$ は、相刘速力と最接近距離の条件によつて決るが、(6)式において 方位の変化率が最大になるような条件の場合、即ち $T_{M}=\frac{d}{V_{r}}$ の関係が成立する時点であり、そ れは最接近距離に比例し、相対速力に反比例する。

（4）同一到達予測時間において、方位の変化率が最大になる条件（ $d=V_{r} T_{M} ）$ の変化率の值 は、相対速力の如何によらず一定であり、その条件は相対速力方゙大きい程、最接近距離の大きい ときに成立する。又、とのような条件を璄として、最接近距離が小さくなるに従つて、方位の変 化率は小さくなり、相対速力の大きい場合の方が、その值が小さくなつている。（図 5 )

次に、このような方位の変化を認知できる最低限界について考えると、人間が認め得る運動 は、最良の条件の下に扔いて、角速度で每秒 1 ～ 2 分、即ち毎分 $1^{\circ} \sim 2^{\circ}$ であるといわれている が、相対簐動の条件下にあつては、更に限界は大きくなると思われる。しかし、方位の変化はコ ンパスによつて観測できるので、コンパスの精度等から考えて、毎分 $1^{\circ} \sim 2^{\circ}$ の変化率を最低限界 考えるととにする。

方位の変化率 1 度 $/ \mathrm{min}$ 及び 2 度 $/ \mathrm{min}$ になる条件を、(6) 式によつて計算すると図 6 のように なる。即ちこの図より各相対速力の場合について、最接近距離と相対方位の変化が僅かであり衝 突の危険性の有無の判断が困難となる時点との関係を知るととができる。

今、回避行動の発動が必要な時機は、Tが 5 分前後のときであると仮定して、以上のような相 対方位の変化の状沉と、その認知のあり方との 関係を総合して考光ると、相対速力の如何によ つて、最接近距離の予測と衝突の危険性の発見 及び評価を行う上に難易があり、自船の行動決 定の状況に差があるととがわかる。

即ち、相対速力が小さい場合には、最接近距 離が小さくても、かなり早い時期より方位の変 化率が大きくなるので、衝笑の危険性の有無の 判断が容易であり、又最接近距離が極めて僅か であつても、回避行動発動の必要な時点附近に おいては、相対距離が近いために最接近罚離の 予測の確度が高くなるので、自船の行動の決定 がかなり容易である。相対速力が大きくなるに 従つて、方位の変化率が $1 \sim 2$ 度/ $\mathrm{min}$ 以上にな り方位の変化を明確に認知できるようになる条

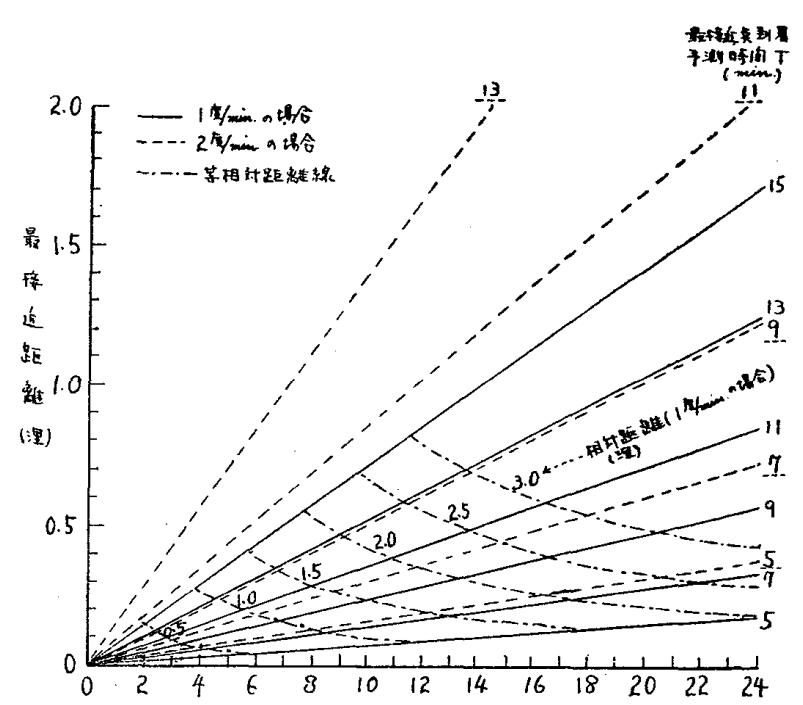

相 対 速 力（節）

図6 相対方位の変化率が $1 \sim 2$ 度/ $\min$ に なる条件 
科の最接近距離は大きくなり、又そのような条件になる到達予測時間（T）は小さくなるので、 方位の変化率にもとずく衝突の危険性の発見及びその評価が困難になるとともに、回避行動発動 が必要な時点の相対距離は大きくなるので最接近距離の予測の確度が低下する。従つて相対速力 が大きくなる程、自船の行動決定が困難になり、慎重な判断が必要になる。又その判断を溃ると 避航時機を失し、緊急な局面に落入る危険性が大きくなる。

しかし、相対速力がかなり大きい惖合には、最接近距離が幾分大きくても、回避行動の発動が 必要な時点附近に到るまで、方位変化率が極めて小さく、又その時点における相対距離が大きく 最接近距離の予測が困難なので、衝突の伦険性を過大に判断し、早期に避航の決定が行われる可 能性が大きいということが考えられる。

以上のような点から、良好な見張が行われている場合、相対速力の小さいときが最も算全連航 の行われる確率が高く、中程度の相対速力の場合に最もその確率が低くなるような条件が存在 し、相対速力がかなり大きくなると再びその確率が高くなるということが考えられる。斎藤浄元 氏が衝乫の要因を分析し、その件数が最も多い接近速力は実際速力 13 節前後であると報告した が、ここで述べた要因とも樑い関係があるのではないかと思われる。

(b) 方位、距離の変化

衝突の危険性の評価に当つては、相対方位の変化とともに、相対距離の変化が関係するが、一 般に他船の方位の変化が極めて小さく、相対距離の変化が大きいとき、衝突の危険性が大きいと いわれている。

相対方位の微小変化にともなう相対距離の変化は、次の式によつて求めるととができる。

即ち

$$
\triangle R=\left(\frac{\triangle R}{\triangle T} \cdot \frac{\triangle T}{\triangle \theta}\right) \times \triangle \theta=\left(\frac{V_{r}^{2} T}{\sqrt{V_{r}^{2} T^{2}+d^{2}}} \cdot \frac{V_{r}^{2} T^{2}+d^{2}}{V_{r} d}\right) \times \triangle \theta
$$

$$
\frac{\triangle R}{\triangle \theta}=\frac{V_{r} T \sqrt{V_{r}^{2} T^{2}+d^{2}}}{d}=\frac{R_{T}{ }^{2}}{d^{2}} \sqrt{\frac{1}{d^{2}}-\frac{1}{R_{T}{ }^{2}}}(\text { 浬/Rad })
$$

しかし、衝突の危険性の評価は、方位の変化率基礎に判断が行われると考えられるので、万 位の変化率が一定な場合における $\triangle R / \triangle \theta 0$ 值を求める式になおすと次のとおりである。

$$
\frac{\triangle R}{\triangle \theta}=\frac{1}{K} \cdot \frac{\triangle R}{\triangle T}=\frac{V_{r}^{2} T^{2}}{K \sqrt{V_{r}^{2}} T^{2}+d^{2}}
$$

但し $K=\triangle \theta / \triangle T$ (方位変化率)

$d<1$ 浬の場合には、 $V_{r}^{2} T^{2} \gg d^{2}$ となるので、 $d=0$ とした近似式によつて得る值と殆んぞ差 がない。即ち

$$
\frac{\triangle R}{\triangle \theta} \fallingdotseq \frac{V_{r}}{K}(\text { 浬 } / \mathrm{Rad})
$$

(9)式より方位変化率が同一条件の場合においては、 $\triangle R / \triangle \theta$ の值は、最接近距離が 1 泚以内の ときその大きさに殆んど無関係であつて、相対速力に比例し、方位の变化率に反比例するという ととがわかる。

(9)式に代表的な数值を入れて作図すると、図 7 のようになる

このような $\triangle R / \triangle \theta$ の值の変化の条件を考慮すると、衝染の危険性の発見及びその評䛧の基 準となる方位の変化率が $1 \sim 2$ 度 $/ \min$ となる条件の場合における相対距離の変化率 $(\triangle R / \triangle T)$ は、相対速力の大きさの差異による危険性の大小の判断起行う上にわいて重要な基礎となるが、 最接近距離に殆んど無関係なので、これにもとずく最接近距離の差異による危険必の大小の判断 は困難であるということがわかる。 
なお、この場合、距離の変化率即ち運動の 涷さに対する認知のあり方は、客観的な運動 に一致しない場合が非常に多く、背景及び物 の大きさと距離に関係する物の恒常性に左右 されるので、相対距離の変化率の值より、実 際の認知の状況を明確に知ることはできな 认。

従つて、衝突の危険性の判断の状況を考察 することは困難であり、この点については、 今後検討を行う予定である。

\section{4. 遭遇確率の高い速力比の船舶 との相対速力}

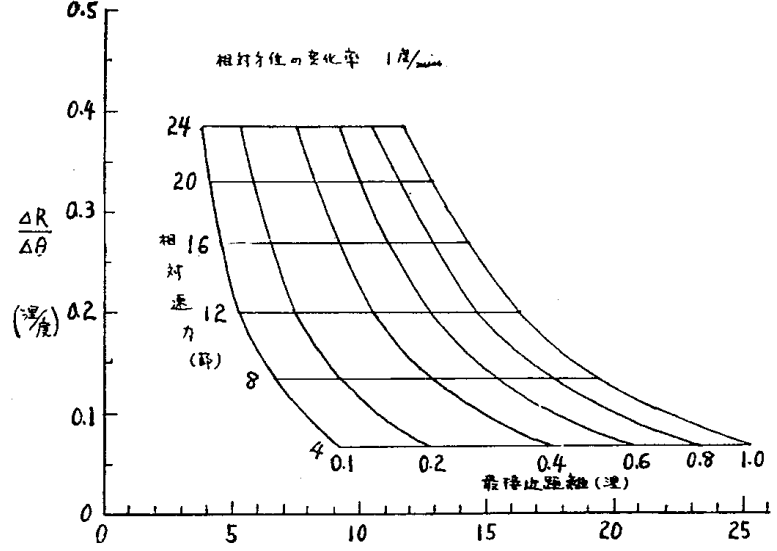

最接近点到着予測時間 $(\boldsymbol{T})(\mathrm{min})$

図 7 相対方位の変化率 1 度/min の時点における $\triangle R / \triangle \theta$ の值

表 2 遭遇の確率の高い船舶間の衝突条件における相対速力

（数值は実際相対速力, 単位: 節)

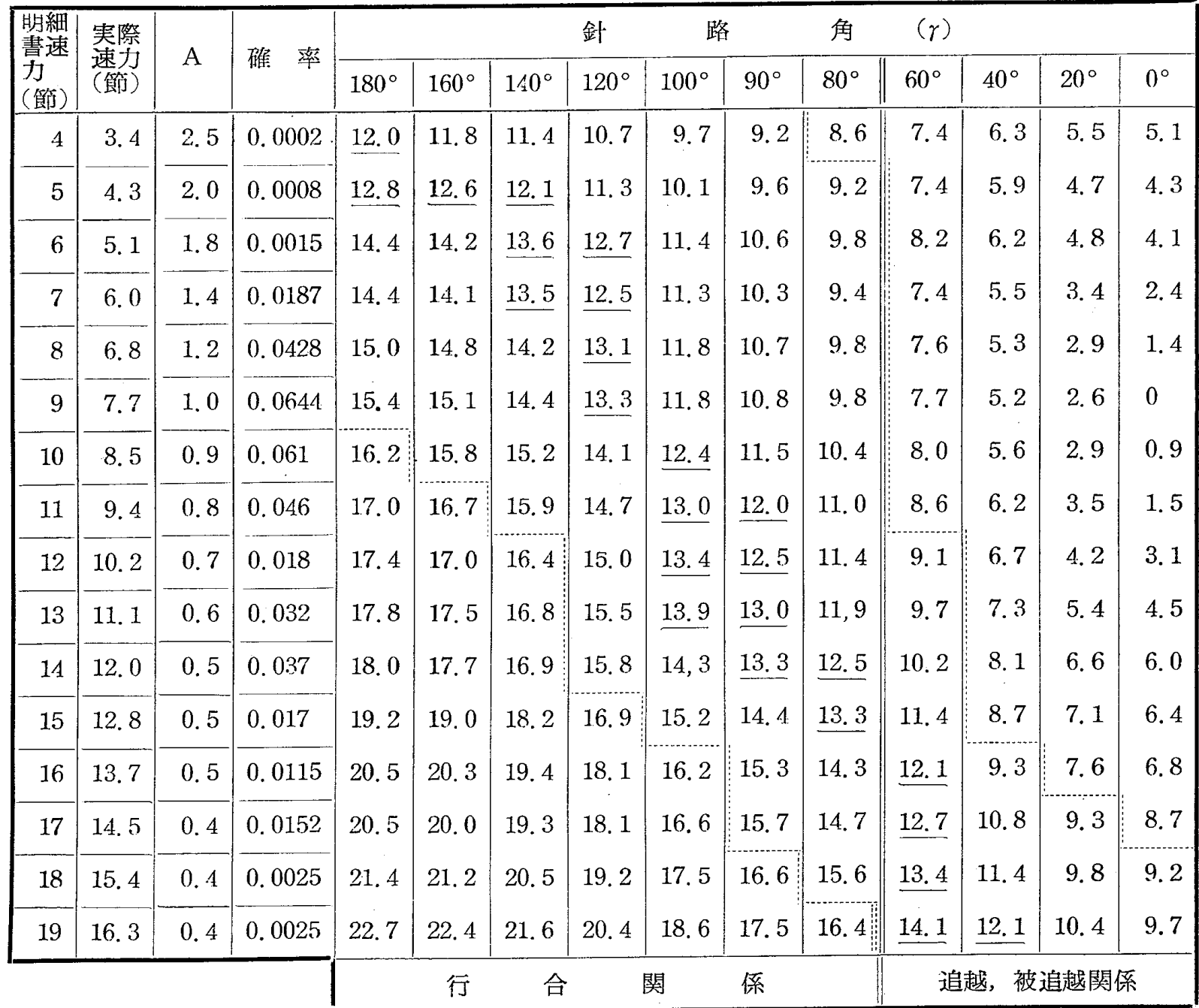

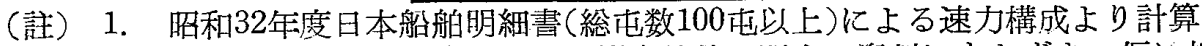

2. 斎藤浄元氏による接近速力と衝突件数に関する資料にもとずき，仮に相対速力16節以上を大 きい速力，9節以上を中速力，9節未満を小さい速力として破線により境界を引いた。アンダー ラインは衙突件数の最も多い相対速力である。 
日本船舶について或る速力の船舶が種々異る速力の船舶と遭遇する確率は表 1 に示したが、速 力比の区分によつて遭遇確率を計算し、更に船船の速力構成にもとずきそれぞれの条件が生ずる 頻度を考慮に入れて、遭遇確率の最も高い船舶の速力比を求めると、表 2 の A 欄の々おりであ る。又その次の闌はこのような条件が生ずる確率奈す。各速力の場合について、Aの欄の速力 此の船舶と種々の針路角で遭遇したときの衝突条件における相対速力（実際速力）を計算すると 表 2 のおりである。

この表により、各速力の船舶について、種々の針路角で衝突条件を生ずる場合、比較的に成立 の頻度が高い相対速力の一般的条件における概略の月やすを知ることができる。

即ち、行合関係（針路角 $70^{\circ}$ 以上）に㧈いては、高速船になる程、相対速力の大きい条件にな 万場合が多く低速船は中程度の相対速力の条件になる場合が多いということがわかる。なお、相 対速力の大きさの区分は、斎藤浄元氏の報告された衝突件数のかなり多い接近速力（実際速力 9 節〜16節）の範囲の基準に行つたのであるが、その妥当性については今後検討を要する。

\section{5. 綜括}

両船の見合関係において、航海士が他船との相対関係を視覚により認知し、衝突の危険性を発

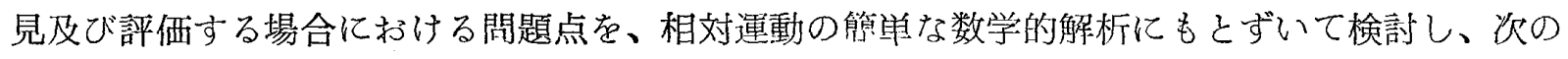
ような点について考察した。

(1) 航行海域を通航する船舶の速力構成、航路事情等によつて異るが、一般に低速船に执いて は、全ての方位から接近する船船に対する衝哭の危険性の有無の判断の難易は殆儿ど差がなく、 速力の高い船になる程、他船の速力について㨁接的に得られる情報の確度にも左右されるが、他 船の方位が約 $30^{\circ}$ より大きい場合に扝ける衝乫の危険性の有無の判断が容易になると考元られ る。(図 4 )

（2）他船との相対速力が小さい場合には、他船の方位及び距離の変化にもとずく衝突の危険性 の評価及び実視による最接近距離の予測の確度が高くなるので、自船の行動決定が容易であり妿 全運航の行われる確率が大きい。相対速力が大きくなる程、両者の確度が低下し、自船の行動決 定が困難になるので、慎重な判断が必要になるが、相対速力ががり大きくなると、衝突の危険 性を過大に評価し、早期に避航の決定が行われる可能性が大きくなる。從つて中程度の相対速力 の場合に安全運航の行われる確率が小さくなるような条件が存在するということが考えられる。

(図 $5 \sim 7$ )

（3）一般に行合関係に㧈いては、低速船は中程度の相対速力の条件になる場合が多く、速力が 高くなる程、相対速力の大きい条件になる場合が多い。（表 2)

\section{参 考 交 献}

1) 斎藤浄元：衝突論 本学会誌 No. 19 (昭33)

2）苧阪良二他：知覚の心理 金子書房 (昭27)

3）空中に扔ける視覚：航空医学資料38（昭33）

4）荒 稲蔵：海上に捛ける監視作業の向上について 航海 No. 8 (1958)

5）滝川文雄：二船が見合ら線 本学会誌 No. 1 （昭24）

6) 横田利雄：海上衝突予防法 海交堂 (昭29)

7) 小松 孝：避航の限界を求むる図表 本学会誌 No. 12（昭30）

8) W. D. Howell \& T. M. Edwards: Determination of some geometric relationships pertaining to collision flight paths, Technical development report No. 259 (1955) 
9) F. J. Wylie: Automation in marine navigation, J. of Inst. Nav. Vol. XII, No. 1 (1959)

10) E. W. Anderson, et al. : Relative movement and the collision problem, J. of Inst. Nav. Vol. X, No. 2 (1957)

12) A. M. A. Mojendie, et al. Blunder and gross human erorrs in navigation, J. of Inst, Nav. Vol. XII, No. 1 (1959) 